\title{
McGill University \\ on the Landscape of \\ Canadian Higher Education: Historical Reflections*
}

\section{by Paul Axelrod}

This article discusses the place of McGill University on the landscape of Canadian higher education in the early twentieth century and attempts to identify some of McGill's unique characteristics. In probing this issue, the author examines selected themes in the academic, administrative and extra-curricular life of the institution, and concludes with some speculative comments about the university's future.

Cet article porte sur la place que l'Université McGill occupait dans l'enseignement supérieur canadien au début du XX $X^{e}$ siècle et tente d'identifier certaines des caractéristiques uniques de McGill. L'auteur se penche sur certains aspects de la vie universitaire, administrative et para-universitaire de McGill et formule quelques hypothèses sur l'avenir de l'Université.

$\mathrm{H}$ development of individual universities in Canada, but their work has rarely been informed by a comparative perspective. While the differences between Canadian and American higher education have drawn. some recent scholarly interest, ${ }^{2}$ academics are still inclined to explore university life through the prism of the single institutional case study in which the experiences of other universities are referenced minimally.

The discussion of McGill University in this article was written for presentation at a 175th anniversary event, and does not escape the institutionalist genre. However, its attempt to identify some unique

\footnotetext{
"This article has been published previously in Higher Educotion Perspectives, Vol. I, 1996/97, a journal of the Higher Education Group, The Ontario Institute for Studies in Education, University of Toronto, and is reproduced here by kind petnission of the Higher Education Group.
}

characteristics of McGill arises from a comparative question: in the early twentieth century, what was McGill's place on the landscape of Canadian higher education? In probing this issue, I examine selected themes in the academic, administrative, and extracurricular life of the institution, and conclude with some speculative comments about the university's future.

\section{Goals of the Canadian University}

Who attended universities in Canada at the turn of the twentieth century and why did they do so? While answers to these questions are far from definitive, case studies of Queen's and Dalhousie suggest that the children of clergy, professionals, merchants, managers and civil servants were particularly well represented among the student body. In addition, more than 30 per cent of Queen's students between 1895 and 1900 were from farming families. Their 
economic status was unclear, though it is likely that they were relatively well off. That not all Canadian students were the progeny of affluence is indicated by the fact that 16 per cent of Queen's registrants were the children of skilled or unskilled workers. ${ }^{3}$

The students aspired to careers in medicine, teaching, engineering, and the ministry. Their actual occupational destinies were somewhat broader. Ultimately, they did indeed work in the areas of health, education and the clergy, but also in science, law, commerce and government. Women graduates who entered the labour force - typically until marriage would find employment in schools, libraries, offices, or as nurses. In most occupational fields, married women were not allowed to continue working and were fired if they did not resign. The Queen's and Dalhousie cases indicate that a higher proportion of university women remained single (and thus employed) than was true of the Canadian female population as a whole.

While we have less detailed information about the origins of McGill students, the national patterns evidently applied there. McGill historian Stanley Frost concluded that, at the beginning of World War I, "the student body was still a compact and homogeneous group of young men and women, mostly from the middle economic strata of society, and of British, or at least anglophone Protestant stock." "If the students' collective profile mirrored the upper end of their communities' class structures, then the average student, at McGill or the University of Toronto was probably somewhat more affluent than his or her counterpart in the more modestly endowed commitinities of Wolfville, Halifax, or Saskatoon. Indeed, at the University of Saskatchewan in 1934, in the midst of the Great Depression, one-third of the students could not afford to pay their tuition fees and instead submitted promissory notes. The situation was by no means so dire at McGill, but during the grim years of the 1930 s, students from poor families, like David Lewis, future parliamentarian and leader of the NDP, could certainly be found.

These trends continued through to at least the Second World War. Canadian students, who in 1930 represented only 3 per cent of their age group, for the most part, came from middle-class families, and through their subsequent occupations or through marriage, they hoped to secure or improve their positions within the middle class. A minority were extremely well off, a minority were poor. Universities were home to a relatively privileged group, but contrary to popular myth, they were not playgrounds of frivolity and ostentation. Neither were they, as charged by one citizen, mere "loafing grounds for rich men's sons," a (1930) comment that among other things, ignored nearly one-quarter of the student body - women. A university education provided the graduate both material opportunity and. the lustre of respectability in an increasingly secular world, though the Depression made it difficult for many students to reap immediately the rewards of. higher learning..

From the perspective of its leaders, the university had a very serious purpose. H.J. Cody, president of the University of Toront, $\mathrm{O}_{3}$ contended that the educated man should be able to "use the mother tongue correctly and precisely," demonstrate "a refinement of manners," be possessed of the "habit and power of reflection," the "ability to grow," and the "power to earn money in the workaday world." McGill spokespersons shared these values. English professor Cyrus MacMillan submitted that "The student who is sent up to college to-day is expected by his parents and those interested in his career to gain along three definite lines: he is to train...his mind...through class-room...study; he is to gain from association with his fellows outside the class-room; [and] he is to benefit from the influence of the college atmosphere on his point of view, his purpose in life, his habits of judgement. These three lines...converge into one main idea - the making of a man," 6 a formula which also ignored university women.

Somewhat less verbosely, Arthur Currie, McGilil's principal from 1920 to 1933, claimed that the university should "place in the plastic minds of the students the seeds of a courageous citzenship...Let students always be devoted to duty."7 Whether one was entering a profession, the business world, or a white-collar occupation, these prescribed qualities were intended to mark the graduate as a. worthy citizen with sound values, lofty morals, enviable education, prized, marketable skills, and the potential of exercising sober community leadership. Though frequently overlooked in convocation addresses, women graduates were also expected by university leaders to contribute to the propriety, refinement and civility of Canadian life, but less as employed workers and professionals than as middle-class wives, domestic organizers, and community volunteers. ${ }^{8}$ Cultivating these myriad attributes was the central mission of 


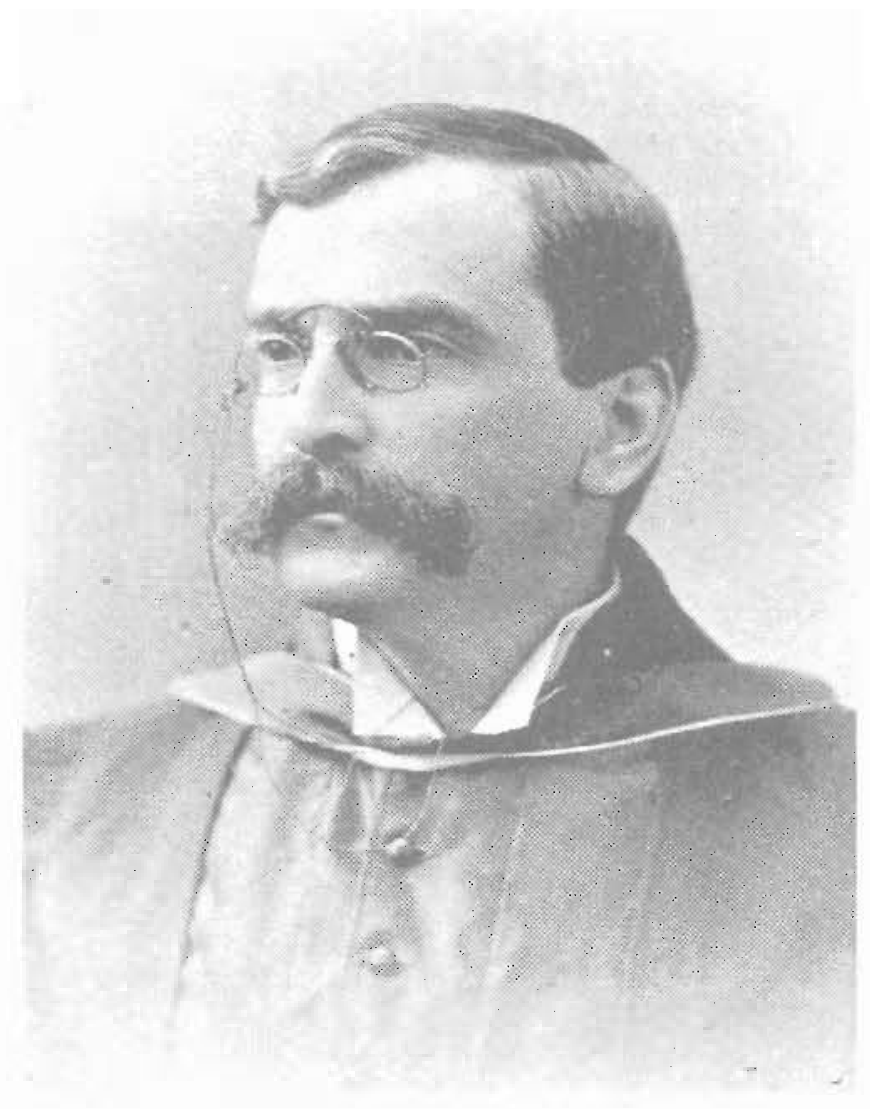

Figure 1. Sir William Peterson, Principal 1895-1919. McGill University Archives, Photographic Collection, PR 008099

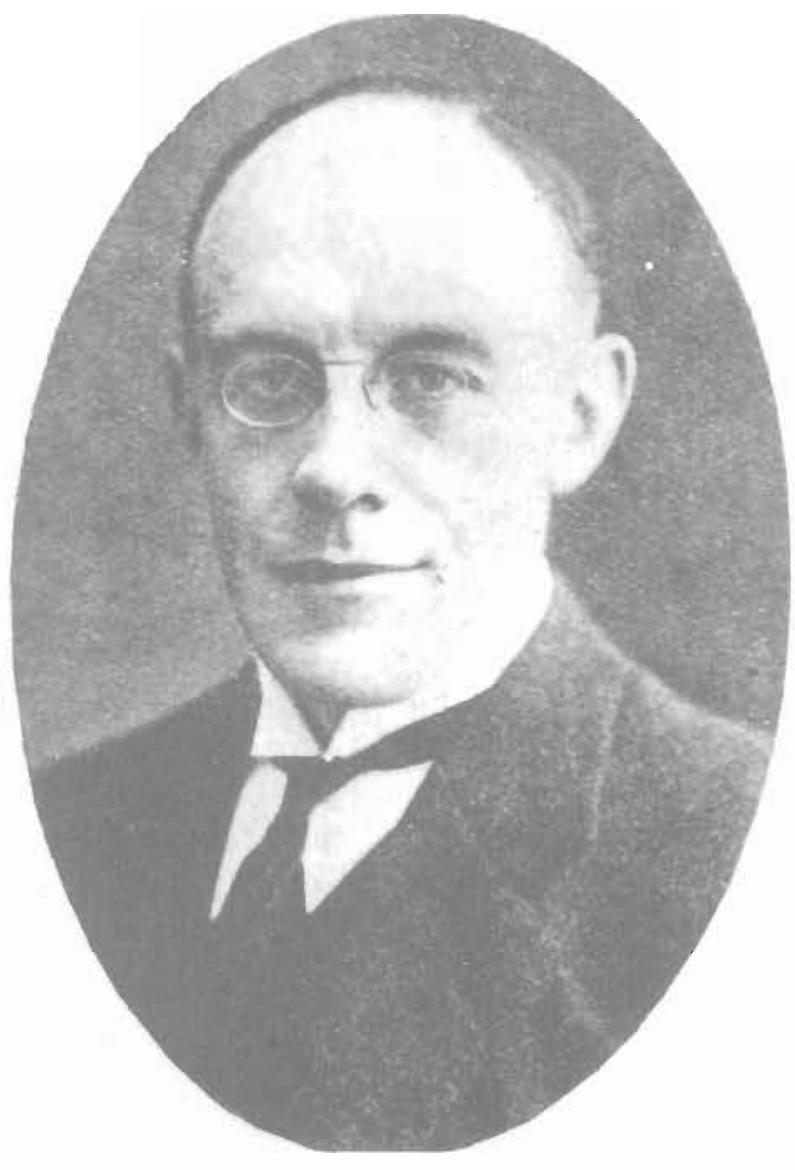

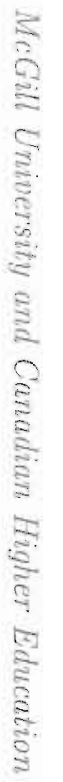

Figure 2. Sir Aukland Campbell Geddes, Principal 1919-1920. McGill University Archives, Photographic Collection. PU 010538. 


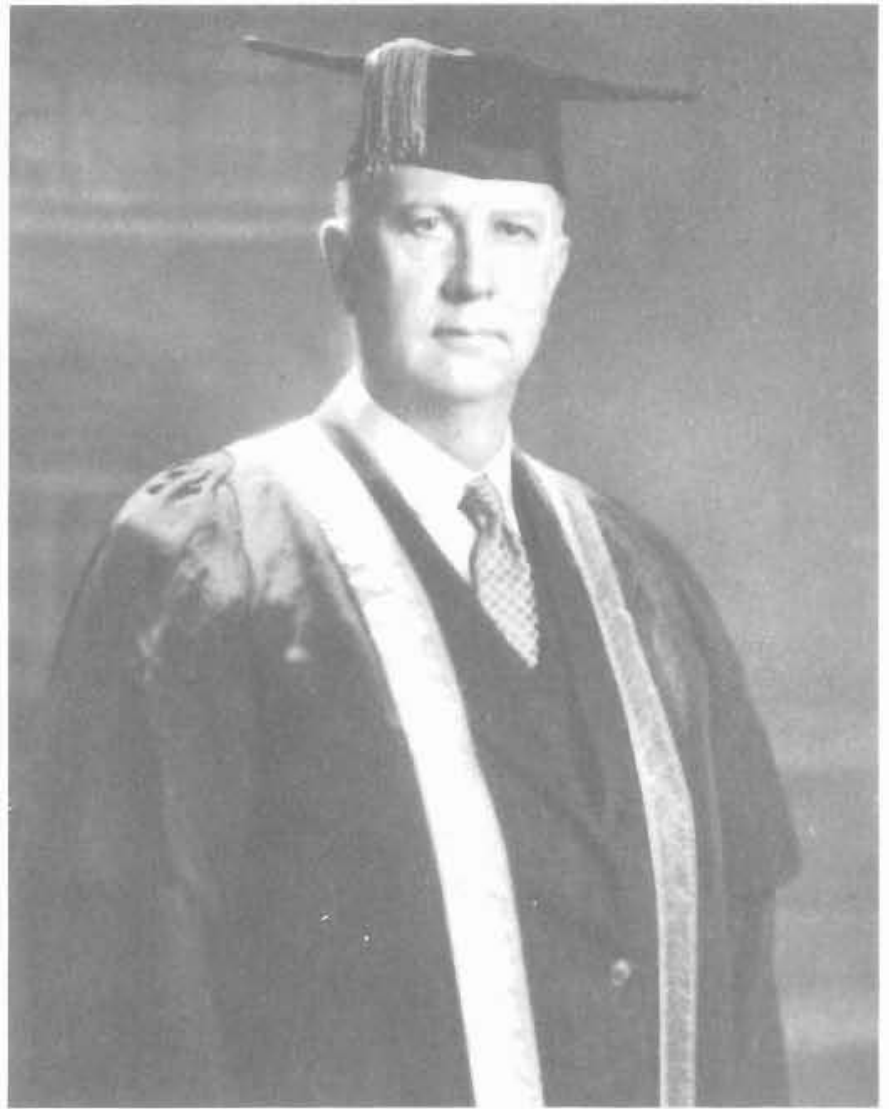

Figure 3. Sir Arthur Currie. Principal 19201933. McGill University Archives, Photographic Collection, PR 010537.

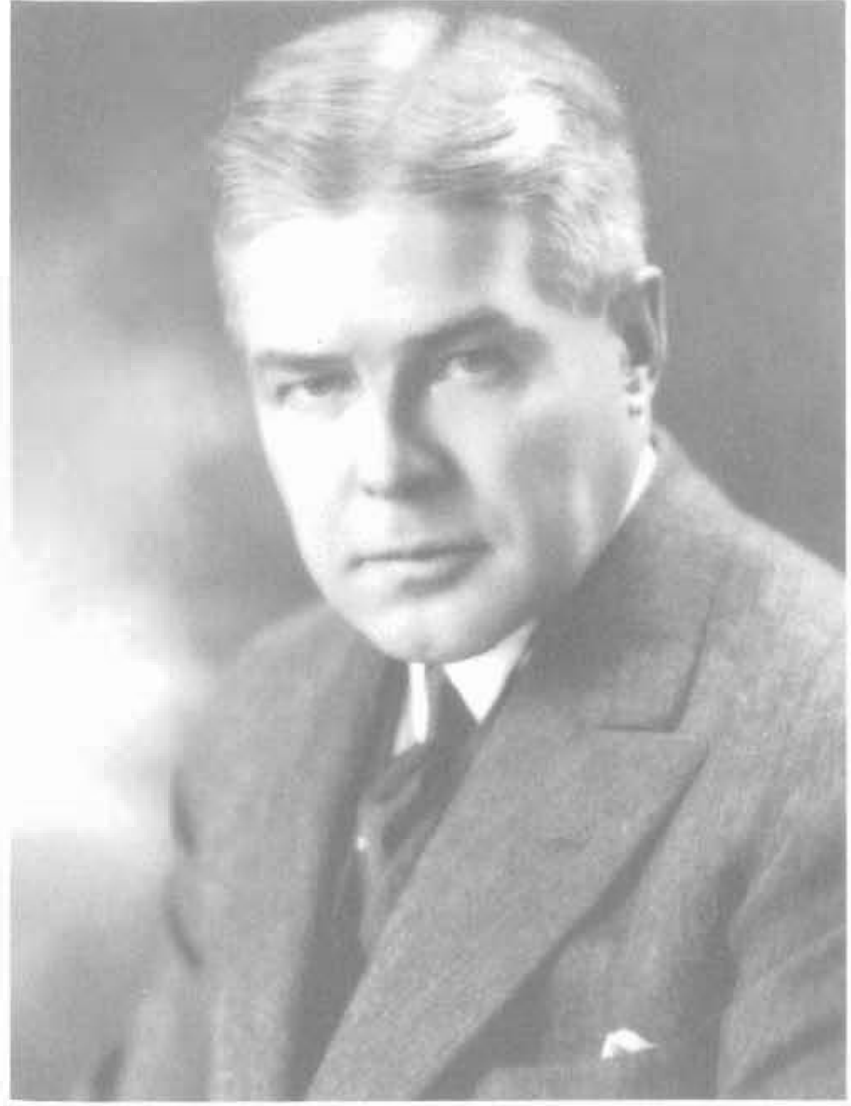

Figure 4. Chancellor Sir William Edward Beatty, de facto Principal 1933-1935. McGill University Archives, Photrophic Colection, PR 001861. 


\section{McGill University and Canadian Higher Education.}

the Canadian university in the early twentieth century.

On the general landscape of Canadian higher education, then, McGill was comfortably placed. But Canadian universities were not identical, and the differences among them, even if subtle, shaped their particular: auras. The following observations are my attempt to capture some unique aspects of McGill.

\section{Utilitarianism}

Perhaps the most distinctive feature of McGill was its history as a private university. For McGill's first 140 years, government funding was minuscule and unreliable. Beginning with the example of James McGili, prominent and frequently wealthy individuals sought to meet the educational needs of their class and community." Lean times notwithstanding, the years of. J.W. Dawson's principalship (1855-1893), witnessed significant donations from Peter Redpath, from the Moison family, and from financier Donald Smith (a.k.a. Lord Strathcona) whose contributions funded the Donalda program. for women's education and the construction of Royal Victoria College. Of course the major benefactor of McGill was the anti-smoking, tobacco manufacturer Willian. C. Macdona.ld, whose association with the university spanned the latter years of the Dawson and most of the William Peterson principalships. ${ }^{10}$ He provided unprecedented funding for science, engineering, an agricultural college, student residences, and chairs in history and moral philosophy, among other things. His contributions to McGill totalled some 14 million dollars, and he is described by one historian as the "greatest educational philanthropist of his day." II

These donations were augmented by the American Carnegie and Rockefeller foundations which, following World War I, subscribed one million dollars each to McGill, partly in recognition of the institution's "outstanding contribution" to the war. A fund-raising campaign in the early 1920s earned 5 million dollars and, between 1920 and 1933, McGill's annual income from all sources increased from $1 \mathrm{mil}$ lion to 2 million. dollars. ${ }^{12}$

Like other Canadian universities, McGill endured a. near fiscal drought during the 1930s, made more challenging by the continuing scarcity of public funding. In 1911, McGill had received all of $\$ 3000$ from the provincial government, in comparison to the $\$ 750,000$ provided to the University of Toronto by the Ontario government. ${ }^{13}$ In 1940, while Canadian universities as a whole received more than 40 per cent of their operating income from governments sources, McGill. secured. less than 10 per cent. ${ }^{14}$

The reliance of McGill on its sponsors and alumni. led to what; was surely one of the most unusual fund-raising campaigns in the university's - and. Canada's - history. In the 1930s McGill sought to raise money for the building of a gymnasium, no less, by distributing its own brand of cigarettes. An advertisement published in the McGill News noted. that of the five billion cigarettes sold in Canada in 1935, "McGill students and graduates smoked some six million of these. At fifty cents per thousand, that would mean $\$ 3000$ " to the gymnasium building fund. ${ }^{15}$

The especially heavy dependence of McGill on private sponsorship, combined with the accomplishments of its most famous researchers, account, in all likelihood, for the institution's particular academic: orientation and for its enviable reputation. Though. the arts were by no means absent at McGill, clearly the lion's share of funding from the 1890s to the 1930s went to medicine, other professions, and the applied sciences. William Osler, whose pioneering work in clinical medicine began at McGill, is described by the Canadian Encyclopedia as the "best known physician in the English speaking world" at the turn. of the century. ${ }^{16}$ Ernest Rutherford won. the Nobel Prize in 1908 for his work on radioactivity. Continuing in the superlative vein, the Canadian Encyclopedia found that he was "considered the greatest experimental physicist of the century."17 Wilder Penfield's decision in the early 1930s to establish the Rockefeller-funded Neurological Institute. at McGill, rather than in the U.S., was certainly $a_{\text {. }}$ coup for the university, as was the innovative work he conducted there. By way of interest, not to be outdone - never to be outdone - McGill political economist Stephen Leacock was described by his biographer in the Encyclopedia as "the Englishspealking world's best known humorist" from 1915 to $1925 .^{18}$

It was McGill's good fortune to come of age in an era when science and technology were in ascendance. The period in which the status of leading universities was linked exclusively to the reputations of their classically-trained clergymen or renowned. gentleman scholars had yielded to an age of utili- 


\section{McGill University and Canadian Higher Education}

tarianism. Institutions and academics perceived to be contributing to the improvement of material life were especially acclaimed. As Robin Harris notes, by 1920 McGill "was unquestionably Canada's most famous university," owing in part "to the enthusiasm of the many Americans who had been attracted to and graduated from its medical school."19

Indeed, when Abraham Flexner of the Carnegie Endowment for the Advancement of Teaching assessed. the quality of medical education in North American universities (1910), he could barely contain his enthusiasm for McGill. Despite being damaged by a recent fire, the university's laboratories were well funded and equipped, showing "what energy and intelligence can accomplish in the face of disaster. The anatomical and pathological museums are among the most famous on the continent. The school possesses an excellent library and all necessary teaching accessories." Clinical facilities "are excellent" and the school "enjoys a most favorable relation to two large hospitals." He had kind words too for the University of Toronto's medical school. By comparison the programs at Laval and Halifax, were considered feeble, and "Western University (London.) is as bad as anything to be found on this side of the line." 20

Principal William Peterson (1895-1919), himself a classicist, had hoped to improve the scope of humanistic studies at McGill, but as E.A. Collard observed, "the benefactors of McGill under his principalship had almost passed by the Faculty of Arts to concentrate their attention on the sciences and professions." 21 That the arts were not totally ignored was indicated by the presence of a number of respected scholars, including classics professor John Macnaughton, who worried publicly in 1904 about the utilitarian orientation of McGill at the expense of more traditional, scholarly values. "It will be black shame to us if it can be said fof an engineer] in his epitaph that he was born a man, went: through McGill University, and died a plumber." 22 In 1911, perhaps as much a statement of resignation as an academic prescription, Peterson wrote: "It is in great measure the pressing demands of industrial and commercial life that are giving our colleges so practical a turn at the present time." 23 Edward Beatty, a prominent businessman, Chancellor of McGill, and its de facto Principal for a two year period in the 1930s, was no major enthusiast of the abstract arts, or even the applied ones. He believed the university's most vital role was to develop the country's natural resources, by teaching "facts." He felt that there had been too much "wandering" in the universe of metaphysics. Students must be prepared for practical work. ${ }^{24}$ Reffecting its acadennic priorities between 1917 and 1939, McGill, along with the University of Toronto, received the overwhelming majority of Nationaj. Research Council post-graduate awards for studies in the sciences. ${ }^{25}$

During World. War II, Principal Cyril James supported a proposal to the National Conference of Canadian Universities that, if implemented, would have dramatically diminished the teaching of arts subjects in Canadian universities in favour of applied, war-related academic programs. ${ }^{26}$ After the war, James confirmed the legacy of McGill's priorities. He noted "the reputation of our greatest names were not forged in the slow studies of humanities and the social sciences, yet McGill, as the greatest privately endowed university, has a unique opportunity in these fields." He called upon McGill to give more attention to these underdeveloped areas of study in the future. ${ }^{27}$

\section{Imperialism}

A symbol of the growing links between education and industrial grawtb. McGill was also a beacon of Canadian nationalism and loyalism through the early twentieth century. Seeking a Principal who was "highly representative of the culture of imperiaJ. institutions," 28 Chancellor Donald Smith found those qualities in William Peterson, a. Scot schooled at Edinburgh and. Oxford, and a Principal of University College at Dundee. Peterson's imperial loyalties were unquestionable, so much so that he appeared to suffer from a permanent; case of homesickness. He was never entirely happy in. Canada, sent his sons to school in Britain, returned there every year himself, and spurned Canadian citzenship.

While Peterson's tentative commitment to Montreal and Canada were grounds for periodic reproval, his patriotic predelictions were shared by McGill spokespersons both before and since. The university recruited as Peterson's successor, Arthur Currie, the war time leader of the Canadian Corps in France. In Stanley Frost's words, "As long as Currie flourished as Principal, the passing of the imperial age and the birth of the new Canadianism were not easily discerned." He spoke frequently at Canadian 


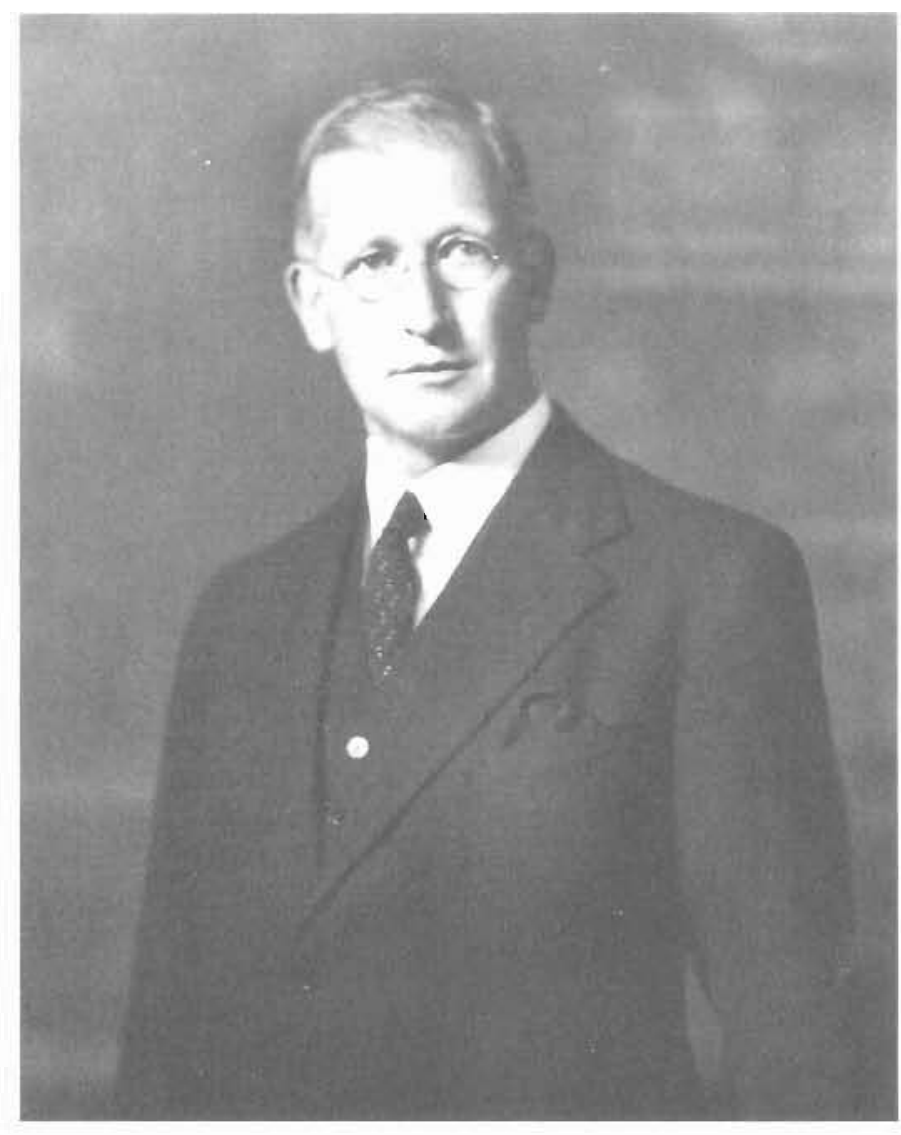

Figure 5. Arthur Eustace Morgan, Principa 1935-1937. McGili University Archives, Photographic Collection, PR 010532.

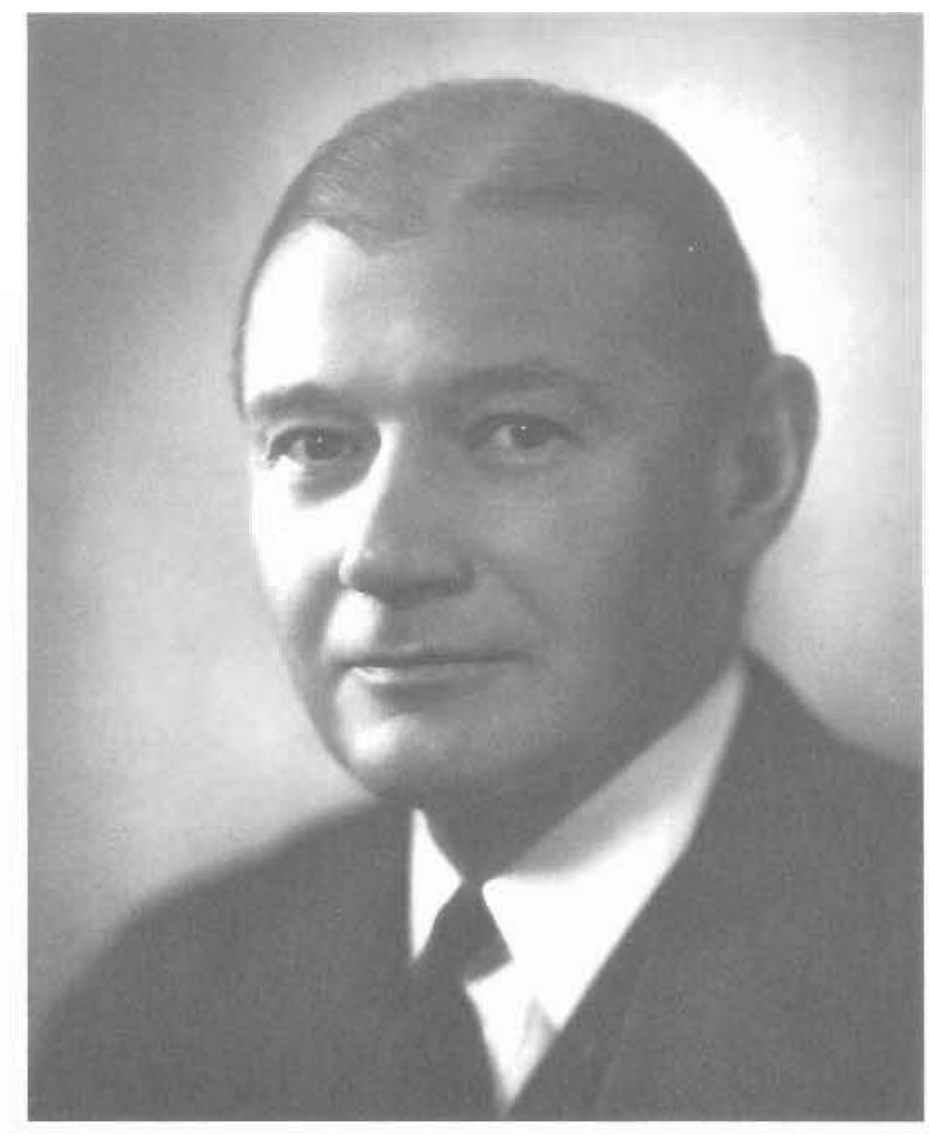

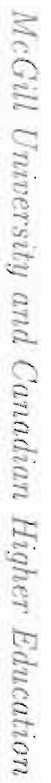

Figure 6. Lewis William Dougias, Principal 1937-1939. McGill University Archives, Photographic Collection, PU 010535. 
Club luncheons, legion rallies, and Armistice day celebrations - serving as a, kind of "father figure for all of anglophone Canada." 29

His successor was an actual Englishman, though, in the end, not of the variety that the McGill board had had in mind when they appointed him. Perceived as idiosyncratic and ideologically unreliable, Arthur E. Morgan, Principal from 1935 to 1937, had nevertheless been plucked from England's Hull College. McGill's perception of itself as an Anglosaxon bastion in a predominantly Frenchspeaking province undoubtedly reinforced its imperialistic orientation.

Other Canadian institutions could also be zealously protective of the imperial connection. In 1937, the University of Toronto reportedly cancelled its library subscription to the American magazine, the New Republic, because of an alleged slur on the King of England. It referred to his "dull and negative personality." 30 Still, it would appear that among universities, McGill's brand of loyalism was second to none in Canada. It was the first university to create a Canadian Officers' Training Corps in 1912; driven by the initiatives of Professor Henry Marshall. Tory, it played a critical role in the creation of the Khaki University for soldiers serving overseas during World War One; in Currie, it had chosen for its Principal a military commander, who was neither a clergyman nor an academic; and its contribution to the wars, in terms of personnel, casualties, research, and. veteran training were substantial, celebrated, and frequently recalled. In sum, its self-innage and identity appeared bound to its Anglo-Saxon mission and legacy, both within Quebec and the wider Englishspeaking community.

\section{Academic Freedom}

The concern for moral and intellectual order informed the purposes and regulations of Canadian universities in the first haif of the twentieth century. Indeed, University of Toronto historian George Wrong claimed in 1931 that "in the main the universities of the western world are strongholds of conservative thought and a steadying infuence on our society. This is not less true of McGill and Toronto than of Oxford and Cambridge."31 Academic freedom, the ability of professors to pursue scholarly work unimpeded by institutional or external restraints, existed in Canada, but as Wrong im- plied, on a qualified basis. This does not mean that universities were merely narrow-minded, intellectual penitentaries. An era which spawned scholars of the calibre of Harold Innis and Northrop Frye could hardly be entirely inhospitable to creativity. No one dared censor the irreverent Stephen Leacock; and his. colleague in the Department of Political Economy, J.C. Hemmeon, whose intellectual and ideological outlook: were liberal and arguably left of centre, enjoyed a long career at McGill. So did poet, Professor of Law, and social reformer Frank Scott, though not everyone at McGill was happy about this. ${ }^{32}$ Furthermore, the McGill Daily; whose rate of publication had no equal among campus newspapers in Canada, was an important outlet for student opinion, and successfully tested, at least on occasion, the boundaries of political propriety and sheer good taste.

But qualifications there were, and those who ran afoul of certain. codes of academic respectability, might well be at risk. Sir Edward Beatty wrote a lengthy, thoughtful and logically tenuous article on academic freedom, which on the one hand defended freedom of thought as "sacred," and on the other claimed that there were "limits within which these liberties may be exercised and that to exceed [them] is not only foolish but wrong." ${ }^{33}$ He claimed that the university must be accountable to its sponsors. If students were taught incorrectly, then "outside the university walls there may well be men competent to detect these errors. Every such case reflects discreditit on the university and shakes public confidence in it."34 At McGill and elsewhere, two types of sins could be committed by incautious professors and irrepressible students: embarrassing the univereity by speaking or behaving in ways which might rouse the ire of the institution's benefactors in government or the private sector; and vigorously promoting the cause of socialism in a. world wary of the prospects of insurgent Bolshevism. ${ }^{35}$ Historians have shown how government officials and the RCMP, in their surveillance and internment practices during the 1920 s and 30 s, at times naively. and at times intentionaliy, blurred the distinction between communists, socialists, outspoken liberals, and civil libertarians. ${ }^{36}$ Universities were touched by this censurious aura, and none more than McGill. It did not help that McGill came under the purview of the Padlock Law, that repressive, loosely worded provincial legislation, passed in 1937, which made it a criminal offence to circulate literature "tending to propagate communisin." 37 


\section{McGill University and Canadian Higher Education.}

Indeed, throughout the Depression, McGill University was frequently criticized by "concerned" citizens for harbouring, if not promoting, communist and/or socialist activism, and university officials were compelled to defend the institution's name. One such allegation came in 1931 from a Baron Eugene Fersen who wrote that "McGill University is contaminated with [Communist] ideas." In this instance, an RCMP Inspector wrote to his Commissioner that it "is ridiculous to think of the University as a hot-bed of Communism." 38 In the same year; Quebec Premier Taschereau advised Currie that, "Several good families of Quebec hesitate to send their boys to McGill on account of the spirit which seems to prevail among some of the professors. May I be permitted to express my surprise that in these hard times the great McGill University should lend a helping hand to socialism." 39 In 1936, the head of the Montreal Police Department's "Red Squad," which scrutinized student meetings, asserted, in response to public complaints, "there is no Red Menace of any description at McGill." At best some students were interested in Communism "in an intellectual way only and discuss it much the same as they would any topic of an educational nature." 40 When the war broke out, tolerance of dissident views among the police and the public diminished even further, and left-leaning organizations and individuals were especially vulnerable. In 1940, some 500 McGill students opposed to the reformist, and anticonscriptionist, Canadian Student Assembly, broke up one of its meetings, and manhandled some of its members. All of this was followed closely and reported on by RCMP agents who actually praised the "loyalty" of the student vigilantes. ${ }^{41}$

Another incident which pointed to the distinctiveness of McGill's social and political environment, occurred in 1936, and involved a confrontation between McGill and l'Université de Montréal students. Three delegates from the anti-fascist, Loyalist government of Spain, were invited to Montreal and, having been denied the right to speak at City Hall, were asked by the McGill Social Problems Club to lecture at the university. A group of students from l'Université de Montréal gathered outside the McGill Union, where the event was to occur, and threw rocks at those on the steps of the building. Later a mob of some 250, consisting mostly of Université de Montréal students, marched through the streets shouting anti-communist and anti-Jewish slogans. They proceeded to the Mount Royal Hotel, where the Spanish delegates were staying and, apparently unprovoked, assaulted a McGill professor. The turbulent weekend ended with a massive anticommunist, pro-Catholic demonstration at Champs de Mars.

Termed a "riot" by the press, these confrontations seemed to symbolize deep political cleavages between students from the two universities, though the majority from both campuses were uninvolved in the events. In the heat of the moment, rhetoric was rife; subsequently, attempts were made by the student councils of both universities to "patch up their differences" by publicly shaking hands and symbolically "burying the berets." To encourage better communication, the editors of the McGill Daily and the Quartier Latin agreed to write columns in each other's papers. This - admittedly extreme - incident signified both the different worlds which French and English Canadian youth occupied, and the efforts by student leaders to forge, in moments of crisis, political accomodation. Such challenges, which faced all of Canada, were of course heightened in Montreal.

French-English relations aside, the activities of certain McGill students were of special interest to the RCMP in this period. The speeches and travels of David Lewis were closely monitored, as were those of the group he headed, the McGill Labour Club. ${ }^{42}$ Indeed, because of their irreverent and critical content, the Alarm Clock, a publication of the McGill Labour Club and the Black Sheep, a magazine which especially angered McGill benefactor J.W. McConnell, and according to Principal Currie, "was a criticism of everything?" were banned from the campus by university officials in $1933 .{ }^{43}$

Sharing a commitment to keeping the campus politcally quiescent, particularly in light of public complaints (however unfounded), Currie and the RCMP had carried on a regular correspondence on the activities of McGill members. As the Commissioner of the RCMP told Currie in 1933, "I am quite satisfied that you are doing all that is possible at McGill to assist in the control of Communism." $44 \mathrm{He}$ looked for similar cooperation at other universities. "It would be a big help if the University Authorities would control the public actions of some of their professors..."

Two of the professors who most worried McGill authorities and its external scrutineers were Eugene Forsey, a lecturer in political economy, and an important figure in the non-communist League for 


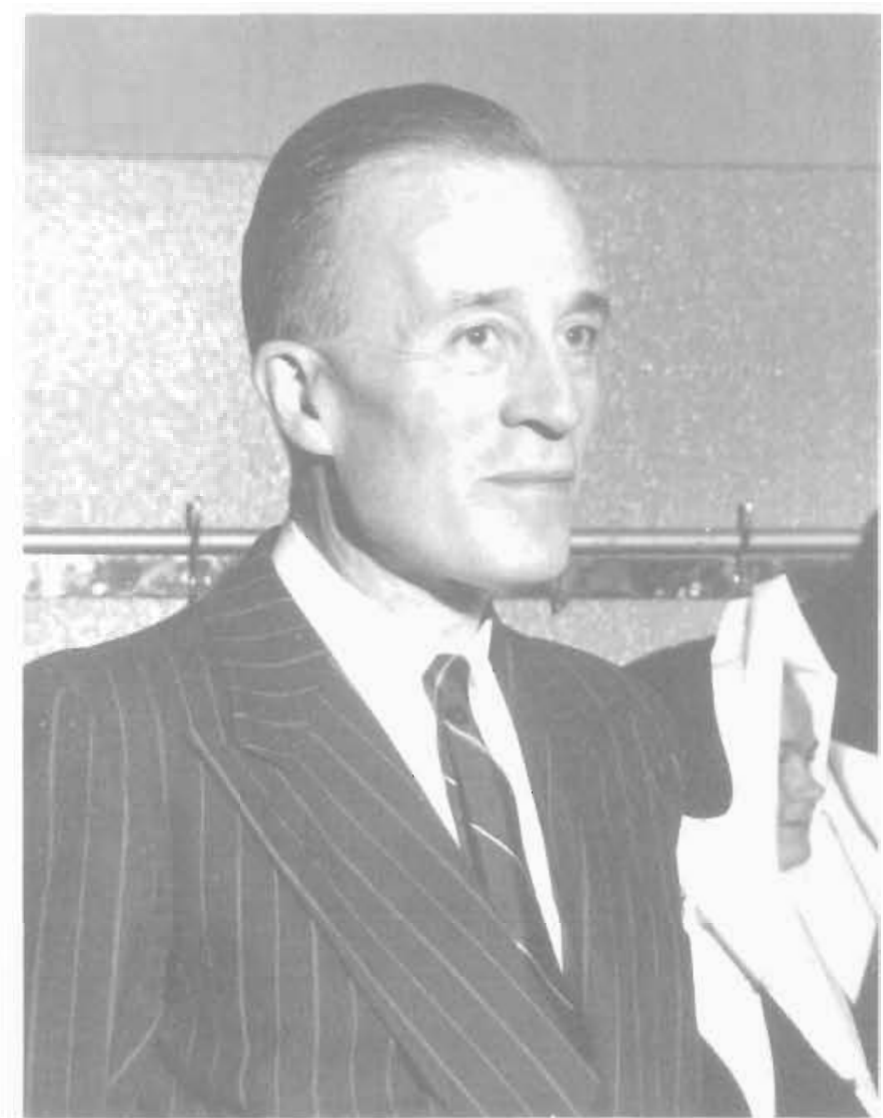

Figure 7. Frank Cyril James. Principal 19391962. McGill University Archives, Photographic Collection, PR 026844.

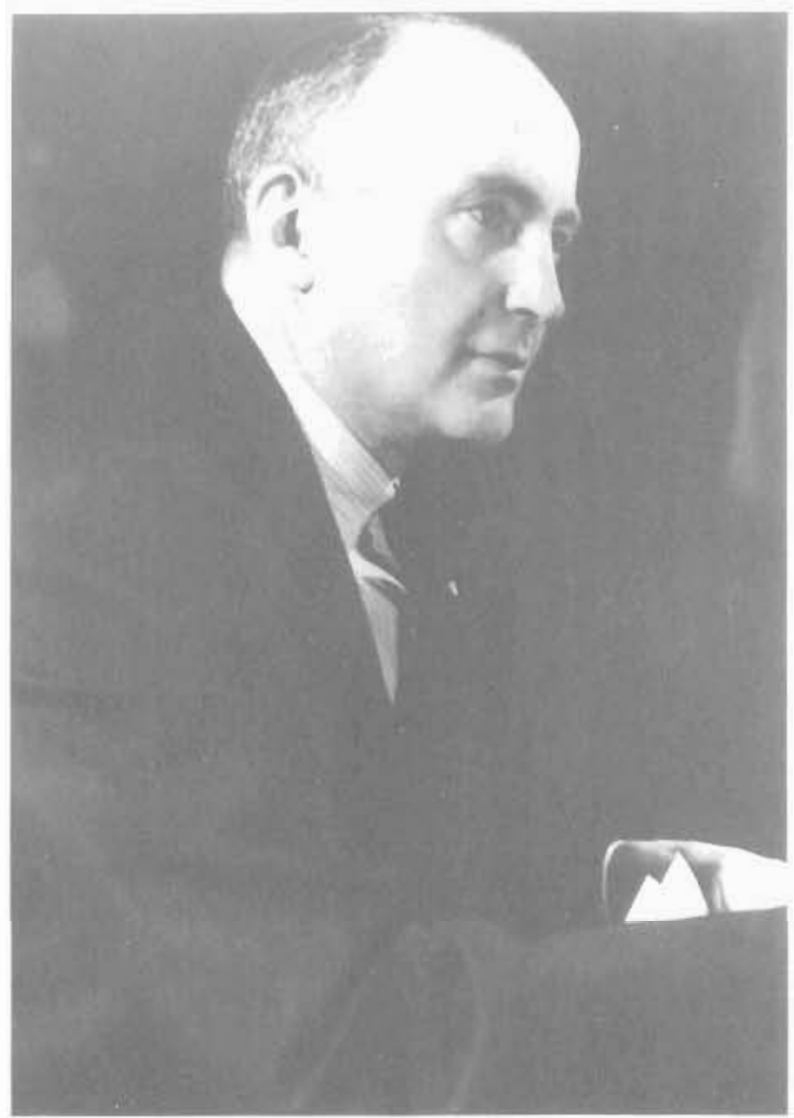

Figure 8. Harold Rocke Robertson, Principal 1962-1970. McGill University Archives, Photographic Collection, PR 023259 
Social Reconstruction, and social scientist Leonard Marsh. Forsey, an outspoken socialist, angered Currie, who believed he roused "a good deal of criticism upon the University for the things he says in his public addresses." 46 Currie told Premier Taschereau. that he had been searching for ways to sack Forsey without provoking a "cause celèbre." He did not want to leave the impression the McGill did not tolerate "freedom of speech." ${ }^{47}$ In response to a complaint about Forsey from A.B. Purvis, President of Canadian Industries and a McGill Board member, Currie wrote "Had I dismissed him, it would have been held to be the arbitrary act of the Principal, whom too many already look upon as the mouthpiece of St. James Street." 48 Under Currie, Forsey kept his job.

Marsh headed the Social Science Research Project, which was funded in 1931 by a Rockefeiler grant, and in the utilitarian spirit of McGill, had originally been designed to explore the relationship between industry and community life in Montreal. Marsh, a Fabian socialist, believed he was well within the project's terms of reference by focusing on the problems of unemployment and poverty which gripped Montreal during the depression. His critics, including Sir Edward Beatty, considered this work too critical of capitalism, and the pressure to curb the project intensified. ${ }^{49}$ During the brief tenure of Principal Lewis Douglas (1937-39), the grandson of a McGill benefactor, an industrialist and former budget chief in the Roosevelt cabinet, the university's appointment rules were rewritten, or at least reinterpreter, in a way that finally allowed for the severing from the university faculty of both Forsey and Marsh. ${ }^{50}$ They both went on to distinguished careers in arademic life and public service.

Was McGill a less tolerant university than others? The views of its leaders in fact were not dramatically different from those of university presidents elsewhere. No institution permitted unqualified freedom of expression; none was consistently authoritarian, though my impression is that universities in western Canada were somewhat less vexed by irreverent student behaviour than those in the east. All worried about leftist faculty and students, far more so, incidentally, than they did about those on the right, including the far right. In the late 1930s, while fascist Adrien Arcand was permitted to speak at $\mathrm{McGill,}$ communist Tim Buck was not. The controversial speeches of Scott and Forsey elicited police attention, but when McGill chemist R.W. Steacie re turned from a trip to Germany and spoke favourably of Hitler in 1935, no complaints were registered 51 The political partisanship of socialist professors was invariably questioned; of conservatives and liberals, virtually never. ${ }^{52}$

In the concern they showed for dissenting faculty and provocative students, the comparative experiences of McGill and the University of Toronto are striking. A report in November 1932 that McGill students had imbibed on a tour of Molson's Brewery led to the dismissal of the managing board of the McGill Daily. At Toronto in 1929, the editor of the Varsity lost his job for acknowledging that "petting" was a common practice among the university's youth ${ }^{53}$

The furor caused by Toronto historian Frank Underhill, who could not stay out of trouble, mirrored the controversies roused at MicGill by the presence of Forsey, Marsh and Frank Scott. Both universities were surrounded and sustained by relatively conservative communities, an aura which undoubtedly affected campis culture. Underhill, however, never lost his job. But two of McGill's heretics did. The university seemed especially sensitive to the views of its benefactors and sponsors. From 1935-39, the governors dug into their own pockets to keep the undversity afioat. As Staniey Frost notes, "Seeing that they were carrying the university financially, it seemed to the governors only just that some of its professors should be presenting the capitalist view of society as vigorously as the socialists were advocating theirs." 54

As we have seen, such private slipport built the university and saw it through hard times, but it may also have made McGill less receptive to minority opinion than was the case at other academic institutions. If the piper did not consistently call the tune, his bellows could scarcely be ignored.

\section{Anti-3emitisin}

McGill was sensitive 10 community opinion in another way that differed not in kind but in degree from its sister universities. Overwhelmingly white, Anglo Celtic, Protestant, and to a lesser degree Catholic, English Canadian universities were determined to preserve their cultural mix. Eike those administering immıgration policy, university officials did this not by banning minority groups but by rigidly controlling thesi numbers. By virtue of 
the significant proportion of Jewish students who sought admission, they were perceived as a particular threat to the composition of the campuses, and extraordinary actions were taken, similar to those in the United States, to limit, and in some cases reduce, their presence.

McGill led the way on this front. In 1924-25, Jews constituted 24 per cent of the arts faculty, 15 per cent of medicine and 40 per cent of law. A major force behind the implementation of a new set of admission policies was Ira. MacKay, Dean of the Faculty of Arts, a man who had once berated David Lewis for his "backward race" and national origin. On another occasion, he wrote, "The simple obvious truth is that the Jewish people are of no use to us in this country...As a race of men their traditions and practices do not fit in with a high civilisation in a very new country." In 1926, he called for the university to limit the proportion of Jewish students in arts to 20 per cent, and in 1934 to reject appeals for the admission to the faculty "of displaced German scholars," many of whom were Jewish refugees. "There are very few questions upon which I am defiant," he stressed to Currie, "but this is one of them." "55

The course followed by the university was, if anything, more restrictive then that recommended by MacKay. While he had suggested that Jewish highschool graduates be required to obtain averages of 70 per cent to çalify for admission, in fact, at the end of the 1930s they needed 75 per cent. By contrast, gentile students achieving 60 per cent were allowed to enrol. Under the impact of such policies, applied with equal vigour in the professional schools, by 1939 Jewish representation had declined to 12 per cent in arts, less than 13 per cent in medicine and 15 per cent in law. ${ }^{56}$

Admission quotas were also applied at the Cniversity of Manitoba, and the University of Alberta. normally refused to enrol Jews from outside the province in the medical school. In 1934, when a Jewish medical graduate was accepted as an intern in Montreal's Hôpital Notre Dame, French-Canadian interns from the University of Montreal walked off the job in protest. In British Columbia, Japanese Canadian students endured the brunt of discriminatory policies. ${ }^{57}$ Throughout the country, including Montreal and Toronto, blacks were banned from clinical practice in most hospitals, and generally prevented from enrolling in university medical programs. Facing what it believed to be an especially menacing challenge, McGill took exceptional actions to stem the ethnic, non-Christian incursion on campus. Happily, these polices at McGill and elsewhere were abandoned in the post-war era, as more liberal social values and enrolment practices finally took root.

\section{The Experience of Women}

For a time in its history, McGill also sought to restrict access of women to its classrooms. J.W. Dawson, Principal in the last half of the 19th century, opposed co-education, and under the terms of a major donation from Donald Smith, McGill adopted a strategy, unique for Canada, of educating women and men in separate classes. The will and resources of the benefactor notwithstanding, segregated teaching proved to be both unacceptable and unaffordable, and co-education gradually became the norm. By 1916 "it was no longer possible for a Royal Victoria College student to complete even her first two years entirely in separate classes." 518

Through the early twentieth century, the experience of McGill women largely paralleled that at other universities, in that they occupied a "separate sphere" both academically and socially. In 1912, McGill did appoint Canada's first female full professor, Carrie Derick, though as Margarei Gillett notes, this did not exactly augui an egalitarian revolution. 59 Women obtained admission only in 1918 to the otherwise innovative Faculty of Medicine. Throughout the country, by 1940 , women dominated the professions of household science, librarianship, nursing, social service, and elementary school teaching. In the professions with higher status, they were practically an invisible minority, comprising 2 per cent of lawyers, 3 per cent of doctors, and less than i per cent of engineers. ${ }^{60}$ Their cause was scarcely aided by perceptions such as those of McGill psychology professor William Tait, who concluded in 1930 that, on the basis of "scientific" evidence, women had less capacity for abstract thought than men owing to the smaller size of their "frontal lobes." Many male students were evidently persuaded by these views. According to a 1939 editorial in the McGill Daily, while men were suited to the economic function of production, "women's qualifications run in the sphere of consumption," supposedly reinforcing their natural connection to the household. ${ }^{61}$

Between the wars, McGill women were barred from running for the Student Council, joining the 
Political Economy Club, or participating in the Mock Parliarent, and rarely did they hold editorial positions on the McGill Daily. As was true at other campuses, women in residence, unlike men, were governed by a panoply of paternalistic curfew and visitation regulations. Female faculty were not, allowed to eat at the "faculty" club. Professor of Library Science Effie Astbury noted that, as late as 1979 , the year of her retirement, it was still customary for women to be addressed as Miss or possibly Ms, but not "Professor."

Women were aware of this differential treatment, and periodically challenged it, but like their fellow students elsewhere, they tended to recall their university years with enthusiasm and affection. When Shirley Goldenberg was admitted as a mature student to the graduate program in the late 1950s, a university official inquired as to the occupation of her husband - a prominent lawyer - and expressed relief that she was unlikely to threaten his status and position. Such indignities aside, she recalled that "My undergraduate years [a decade earlier] could not have been happier." 6.3 Margaret Grant, who graduated in 1933, remembered the sport that women had defying residence rules, and spoke fondly of the sense of community that thrived among her classmates. ${ }^{64}$ Author Constance Beresford-Howe, who would eventually teach st McGill, was inspired by her fourth year instructor, Gertrude Mason. "She breathed such passionate life into Anglo-Saxon literature, Chaucer and Jacobean dramatists, that her students couldn't easily avoid becoming infatuated with them." 65 in this era, women derived from their universities not equality of treatment, but the possibility of camaraderie that made campus life rewarding, and, given the intellectual and social skills they acquired, a margin of independence that would ultimately serve them well in the workplace, at home, and in their communities. ${ }^{.6}$

\section{Post-War Challenges}

As Canadian universities entered an era of unprecedented expansion in the late $1950 \mathrm{~s}$ and $60 \mathrm{~s}$, the characteristics which had distinguished them, to some degree, diminished. Collectively, they were pressured to provide adequate space for a generation of post-war baby boomers; consequently enrolments ballooned. They were perceived, more than ever, to be instruments of economic utility and consumed unprecedented amounts of public funding, which in McGill's case began in earnest in 1963. All universi- ties were reformed in the wake of the student movement of the $1960 \mathrm{~s}$. The institutions virtually abandoned the goal of attempting te cultivate character and regulate social lives, and students, including women, won more autonomy. Universities developed academic programs that offered more breadth and choice, and university faculty gained a greater role in institutional decision making. ${ }^{67}$ At McGill the fields of physics and chemistry remained major priorities, but the arts too, responding to contemporary student interest, achieved a far higher status than in earlier eras. Relations with the Quebec government ranged from tense to accomodating, amid a political atmosphere that was frequently charged and uncertain, perhaps never more than at present. ${ }^{68}$

Today, all universities are consumed by the challenge of how to maintain enrolment, quality and morale in the face of public funding rollbacks. A clue to McGill's future strategy can be found in a statement called "Towards a New McGill," delivered by Principal Bernard Shapiro on October 1, 1995. As he saw it, McGill's financial difficulties were compounded by the shrinkage of the Anglophone population of Montreal, and by the political instability generated by the sovereigntist movement. But the institution's assets, literally, were significant. They included the loyalty and generosity of its alumni, which "provide a strong basis for private funding," and a projected $\$ 500$ million endowment trust, enhanced by the most recent fund-raising campaign. McGill had "established strengths in research" and a "reputation for excellence...particularly in the areas of privately funded teaching programmes," which should facilitate new partnerships with "other universities or with industry." The Principal's downto-earth proposal anticipated a smaller unversity, dependent again upon its own resources, carefully selecting its priorities, as it secures an appropriate niche in the academic and globai marketplaces. In this vision of McGill's future, there are echoes of its past. ${ }^{69}$

\section{Conclusion}

The writing of institutional history is a valuable, and frequently essential, precondition for mapping a country's educational experience. A fuller picture of the cultural landscape, however, requires that one university's story be set in a wider analytical context. This paper has sought to explore selected aspects of McGill's history against the background of Canadian university development, focusing primar- 
ily on the first half of the twentieth century.

Devoted, like other universities, to the task of preparing a select, group of young people for middle class occupations, McGill was especially dependent on the material and moral support of its anglophone sponsors. While turning inward for the resources that sustained it, it cultivated an important educational role within a wider English-speaking universe, where it was best known for its scientific endeavours. Given its fiscal vulnerability, and the conservative inclinations of the community it served, McGill ws particularly sensitive to episodes that might sully its image. Iconoclastic professors and students were allowed autonomy - within limits. As the university's academic spirit became more liberal, and its admission policy more inclusive, its record of accomplish-ment sustained its status and reputation. ${ }^{70}$ McGill's apparent response to current challenges is to narrow its academic focus. It remains to be seen whether this strategy will help maintain or diminish its elevated place on the Canadian educational landscape.

\section{NOTES}

1. This is a revised version of an. invited address delivered to the James McGill Society of McGill University on April 29, 1996. The presentation was cosponsored by the McGill Institute for the Study of Canada. I would like to thank Professor Michiel Horn of Glendon College, York University, for permission to cite material from his forthcoming book on the history of academic freedom in Canada.

2. Michael L. Skolnik and Glen A. Jones, "A. Comparative Analysis of Arrangements of State Coordination of Higher Education in Canada," Journal of Higher Education 63, 2(Mar./Apr. 1992): 121-1.42; Henry Srebnik, "Football, Frats, and Fun vs Commuters, Cold, and Carping: The Social and Psychological Context of Higher Education in Canada and the United States," in Canada and the United States: Differences that Count, ed. David. Thomas (Toronto: Broadview Press, 1993), 380407; Paul Axelrod, "Higher Education in Canada and the United States: Exploring the Roots of Difference," Historical Studies in Education 7, 2(1995): 141-175. A most significant departure from the institutionalist approach is A.B. McKillop, Matters of Mind: the University in Ontario, 1791-1951 (Toronto: University of Toronto Press, 1994).

3. Chad Gaffield, Lynne Marks, and Susan.
Laskin, "Student Populations and Graduate Careers, 1895-1900," pp. 3-25; and Judith Fingard, "College, Career, and Community: Dalhousie Coeds, 1881-1921," pp. 26-50, in Youth, University and Canadian Society: Essays in the Social History of Higher Education, ed. Paul Axelrod and John G. Reid (Montreal: McGill-Queen's University Press, 1989).

4. Stanley Brice Frost, McGill University for the Advancement of Learning, Volume II, 1895-1971 (Montreal: McGill-Queen's University Press, 1984), 폰. 125 .

5. Paul Axelrod, Making a Middle Class: Student Life in English Canada during the Thirties (Montreal: McGill-Queen's University Press, 1990), p. 22 and passim.

6. Cyrus MacMillan, "The University and the Freshman," The University Magazine 10, no. 2 (April 1911): 210.

7. Cited in Hugh M. Urquart, Arthur Currie: The Biography of a, Great Canadian (Toronto: J.M. Dent and Sons Canada Ltd., 1950), 348.

8. Axelrod, Making a Middle Class, pp. 92-93, 118-121.

9. Stanley Frost describes the founders of McGill as "Montreal businessmen who needed education for their children and who were prepared to create and sustain the institution. which could supply that need." Stanley Brice Frost, "Who Runs This Place Anyway?" in Graduates' Society of McGiil University, McGill: A Celebration (Montreal: McGillQueen's University Press, 1991), p. 64.

10. For a biographical portrait, see Stanley Frost and Robert Michel, "Sir William Macdonald: An Unfinished Portrait," Fontanus, Vol. VIII, 1995: 5979.

11. Robert Stamp, "Evolving Patterns of Education: English-Canada from the 1870 s to 1914, , in Canadian Education: A History, eds. Robert Stamp, J.D. Wilson, W.P. Audet (Scarborough, Ont.: Prentice-Hall, 1970), p. 332 and Frost, McGill University: For the Advancement of Learning, passim. See also Yves Gingras "The Institutionalization of Scientific Research in Canadian Universities: The Case of Physics," Canadian Historical Review LXVII (no. 2), 1986: 185-6, for a discussion of the importance of Macdonald's contributions to physics at McGill. 
12. Robin S. Harris, A. History of Higher Education in Canada, 1663-1960 (Toronto: University of Toronto Press, 19'76), p. 357.

13. Frost, McGill University: For the Advancement of Learning, p. 86.

14. McGill University, Annual Report, 1940-1941, p. 107; Statistics Canada, Historical Compendium of Education Statistics from Confederation to 1975 (Ottawa: Statistics Canada, 1978), p. 250.

15. McGill News 17, no. 4, 1936 (McGill University Archives)

16. Charles G. Roland, "William Osler," The Canadian Encyclopedia (Edmonton: Hurtig, Press, 1985), 1340-1.

17. Yves Gingras, "Ernest Rutherford," Itid, $1610-11$.

18. Gerald Lynch, "Stephen Leacock," Jbid, p. $989-90$.

19. Harris, A History of Higher Educotion in Canada, 1663-1976 pp. 218, 219.

20. Abraham Flexner, Medical Education the United States and Canada: A Report to the Carnegie. Foundation for the Advancement of Teaching (New York: Anro Press and the New York Times, 1972 , originally published 1910), pp. 324, 325 .

21. E.A. Collard, "Sir William Peterson's Principalship, 1895-1919," in McGill: The Story of a University, ed. Hugh MacLennan (London: George Allen and Unwin, 1969), p. 84.

22. Cited in Frost, McGill University: For the Advancement of Learning, p. 54.

23. William Peterson, Canadian Eissays and Addresses (London: Longman's Green and Co., 1915), p. 318.

24. Cited in Marlene Shore, The Science of Social Redemption: McGill, The Chicago School, and the Origins of Social Research in Canada (Toronto: University of Toronto Press, 1987), p. 22.

25. McGill received 325, Toronto, 233 and all other Canadian universities combined, 153. See Yves Gingras, "Financial Support for Post-graduate Students and the Development of Scientific Research in Canada," in Youth, University ana Canadian Society: Essays in the Social History of Higher Education, p. 312 .

26. The best account of this episode is in Frederick G. Gibson, To Serve and Yet Be Free: Queen's Uni- versity, Volume II, 1917-1961, (Montreal: McGillQueen's University Press, 1983), pp. 208-14.

27. Cited in R.C. Fetherstonaugh, McGill University at War (Montreal: McGill University, 1947), p. 362.

28. Frost, McGill University: For the Advancement of Learning, p. 6.

29. Frost, McGill University: For the Advancement of Learning, p. 131.

30. Axelrod, Making a Middle Class, p. 138.

31. Cited in Michiel Horn, The League for Social Reconstruction (Toronto: University of Toronto Press, 1980), p. 182.

32. Michiel Horn, "Academic Freedom and the Canadian Professor," CAUT Bulletin, December, 1982, pp. 19-22. Frank Scott recalled "numerous instances of being asked to tone down his statements about public affairs or to reduce his involvement in politics...He was kept from the deanship of the Faculty of Law long after it should have come to him according to the practices of the Faculty and the University."

33. Sir Edward Beatty, "Freedom and the University, Queen's Quarterly XLIV no. 4 (1937): 463-71. Quote from p. 467.

34. Ibid, p. 468.

35. A detailed discussion of conflicts, not only between students and university authorities, but among students themselves, can be found in Charles Levi, " 'Decided Action Has Been. Taken': Student Government, Student Activism, and. University Administration of the University of Toronto and McGill University; 1930-1950," unpublished graduate research paper, York University, 1993.

36. See Paul Axelrod, "Spying on the Young in Depression and War: Students, Youth Groups and the RCMP', 1935-42 Labour/Le Travait 35 (Spring 1995): 43-63; S.R. Hewitt, "Spying 101: The RCMP's Secret Activities at the University of Saskatchewan, 1920-1971," Siaskatchewan History 42, no. 2 (Fall 1995): 20-31; Reg Whitaker, "Official Repression of Communism During World War II," La,bour/Le Travail 17 (Spring 1986): 135-167.

37. John Thompson and Allen Seager, Canada, 1922-1939: Decades of Discord (Toronto: McClelland and Stewart, 1987), p. 285.

38. Montreal Gazette, 1 May 1931; J.W. Phillips 
to Commissioner Cortlandt Starnes, 9 May 1931; Cortlandt Starnes to Arthur Currie, 13 May 1931, Canadian Security Intelligence Service (CSIS) Files, in possession of the author following application through the Access of Information Act.

39. Michiel Horn, "Socialism at McGill," unpublished chapter from his forthcoming book on the history of academic freedom in Canada.

40. Montreal Standard, 18 April 1936, clipping in CSIS Files.

41. Paul Axelrod, "Spying on the Young in Depression and War..." p. 52.

42. Report on Lewis speech followed his trip to Russia, 16 May 1931, and on a speech by Forsey, 14 Jan. 1932 (CSIS Files). See also Michiel Horn, The League for Social Reconstmuction: Intellectual Origins of the Democratic Left in Canada, 19301942 (Toronto 1980).

43. Arthur Currie to J.H.B. MacBrien, Commissioner of the RCMP, 11 Feb. 1933 (CSIS Files).

44. MacBrien to Currie, 13 Feb. 1933.

45. Ibid.

46. Horn, "Socialism at McGill", p. 4.

47. Horn, p. 9.

48. Currie to Purvis, Oct. 23, 1933, RG2 C42, F301 Principal's Papers, File: Communism \& Socialism: Forsey, Gordon and Scott, and the CCF, McGill University Archives.

49. Horn, p. 15.

50. Marlene Shore, The Science of Social Redemption, p. 21; Horn, "Socialism at McGill", pp. 26-31.

51. Horn, p. 18-19.

52. This is confirmed in the letter from Currie to Purvis cited above (Note 48). He lists all of the members of the Economics department, and describes their political affiliations. All except one were described as being "Liberal" or "Conservative" and thus no threat to the university.

53. Axelrod, Making a Middle Class, p. 114.

54. Frost, McGill University, For the Advancement of Learning, p. 196.

55. David Lewis, The Good Fight: Political Memoirs, 1909-1958 (Toronto: MacMillan of Canada, 1981), p. 23; Ira A. McKay to Arthur Currie, April 23, 1926, Jewish Students at McGill, RG2 C48, Principal's Papers, MUA; See also Axelrod, Making a
Middle Class, pp. 32-3.

56. Stanley Frost and Sheila Rosenberg, "The McGill Student Body: Past and Future Enrolment," McGill Journal of Education 15, no. 1 (Winter 1980): 41-3. See also Axelrod, Making a Middle Class, pp. 32-4.

57. David Rome, Clouds in the Thirties: On AntiSemitism in Canada, 1929-1939 (Montreal: National Archives, Canadian Jewish Congress, 1979), pp. 36-54; Elaine Bernard, "A University at War: Japanese Canadians at UBC During World War II," BC Studies, no. 35 (Autumn 1977): 36-55.

58. Paula J.S. LaPierre, "The First Generation: The Experience of Women University Students in Central Canada," Ph.D. thesis, University of Toronto, 1992, p. 148.

59. Margaret Gillett, We Walked Very Warily: A History of Women at McGill (Montreal: Eden Press Women's Publications, 1981), pp. 4-5.

60. See Making a Middle Class, pp. 153-4.

61. William D. Tait, "Some Feminisms," Dalhousie Review 10 (1930-32): 52-3; McGill Daily, 26 Oct. 1939.

62. For this and other recollections, see Margaret Gillett and Kay Sibbald, eds., A Fair Shake: Autobiographical Essays by McGill Women (Montreal: Eden Press, 1984), p. 263.

63. Ibid, p. 252.

64. Ibid, p. 29.

65. Ibid, p. 34.

66. Axelrod, Making a Middle Class, pp. 35-7, 116-122.

67. On the post-war period, see Edward Sheffield, "The Post-War Surge in Post-Secondary Education: 1945-69," in Wilson, Stamp, Audet, eds., Canadian Education: A History, pp. 416-443; Paul Axelrod, Scholars and Dollars: Politics, Economics and the Universities of Ontario, 1945-1980 (Toronto: University of Toronto Press, 1982); David M. Cameron, More than an Academic Question: Universities, Government, and Public Policy in Canada (Halifax: The Institute for Research on Public Policy, 1991).

68. Frost, McGill University: For the Advancement of Learning, Parts II and III.

69. Bernard Shapiro, "Towards a New McGill," Statement to Senate and Board of Governors of McGill University, October 1, 1995, released on In- 
McGill University and Canadian Higher Education

ternet, Jan. 15, 1996.

70. One controversial indication of this is McGill's consistently high ranking in Maclean's annual survey of Canadian universities. 